\title{
LAND USE CHANGES OF RAJAHAR VDC, NAWALPARASI DISTRICT, NEPAL
}

\author{
Dhurba Prasad Ghimire, Sunil Babu Khatry and Bhagawat Rimal \\ College of Applied Sciences-Nepal (Affiliated to Tribhuvan University), Kathmandu \\ Email: gp.dhurba01@gmail.com
}

\begin{abstract}
A digital land use map of the study area Rajahar VDC at Nawalparasi district was prepared with the aid of RS/GIS for 1989 to 2013 followed by land use map analysis. The obtained image was classified as forest, agricultural, settlement, water body and religious areas for the study year 1989 to 1999 where industrial area was included as new land use category $(0.07 \%)$ for 2013 . The study showed that there was considerable change in forest area $(-3.47 \%)$ and religious area $(-0.01 \%)$. But agriculture land, settlement area and water body were increased by $2.02 \%, 3.66 \%$ and $1.28 \%$, respectively. The land use change for 1989 to 2013 followed polynomial $\left(\mathrm{R}^{2}: 0.6577\right)$ pattern. The identified land use change key drivers were dependent on past events and reactions of the respondents.
\end{abstract}

Key words: Land use change; GIS and RS.

\section{INTRODUCTION}

The land use change has become a central component in strategies adoption for managing natural resources and tracking environmental changes. The land use incorporates broad categories like human settlements, protected area, agricultural area, industrial zone, residential zone, etc. Land cover refers to the observed biophysical cover (forest, grassland, etc.) on the land that characterizes a particular area (CIESIN 2002, FAO 2005, Briassoulis 2006, Lamichhane 2008). There is an established direct linkage between land use activities of local people (Phong 2004, Lamichhane 2008) in response to earth's fundamental characteristics and processes (land productivity, biodiversity, biochemical and hydrological cycles). The number of people dependent on the agriculture is rising; as a result agricultural land has increased through forest encroachment (CIESIN 2002). The changes in land cover can have far reaching consequences to increase of population and intensive agriculture at local, regional and global levels (Rimal 2011). Land cover changes comprise of land variations and intra modifications (Meyer and Turner 1992).

The use of GIS enables the synthesis of both natural resources and environmental data (forest cover, drainage basin, agricultural crops) together with social characteristics (villages/houses location, resident names, demography, etc.). The analysis of remote sensing (RS) input data involves information extraction through a quantitative modeling approach (Dai and Khorram 1999). Satellite RS data have been used in Nepal for past 
two decades in specified areas (Sharma 2002). Nawalparasi, one of the Terai districts with unique biological, hydrological and ecologically characteristics, needs special attention in the context of land use change. The biodiversity losses due to the landscape changes especially in the Terai forest and agricultural land need to be dealt.

\section{MATERIALS AND METHODS}

The study was carried out in Rajahar Village Development Committee area of Nawalparasi district, with geographic location of Latitude $27.68588^{\circ} \mathrm{N}$, Longitude $084.24957^{\circ} \mathrm{E}$ expanded over $40 \mathrm{sq} \mathrm{km}$ area. It is situated at about 193 masl and $22 \mathrm{~km}$ from nearby Kawaswati Bazar to its west, $25 \mathrm{~km}$ east from Narayanghat. It lies in and is intersected by Mahendra Highway. It is bordered by Jharai Khola (Amarapuri and Ratnanagar VDC), Mukunde Khola (Dibyapuri VDC) on west, Dandajheri and Kotthar VDC on south and Narayani River (Chitwan) at north (Fig. 1).
The Digital topographical maps on the shape file of scale 1:25,000 of the Rajahar VDC were collected from the Department of Survey, Kathmandu (DoS). The research VDC area was extracted from that topographic map by clipping tool of Arc GIS 9.3. The land use/land cover change pattern was conducted by Geographic Information System (GIS) and Remote Sensing (RS). The satellite image consulted during the research, i.e., land sat image 5 Thematic Mapper satellite image(TM) 1989, Landsat 7 Enhanced Thematic Mapper satellite image (ETM+) 1999, and Landsat image 5 Thematic Mapper satellite images (Landsat8) 2013 were used for quantification of land cover of Rajahar VDC (Fig. 2, Table 1). All data were collected from Department of Survey and acquired through wide web internet sources, which comprised of the Landsat image of $30 \mathrm{~m}$ spatial resolutions of raster data and image classified according to the image classification scheme of Anderson et al. (1976) image analysis techniques.

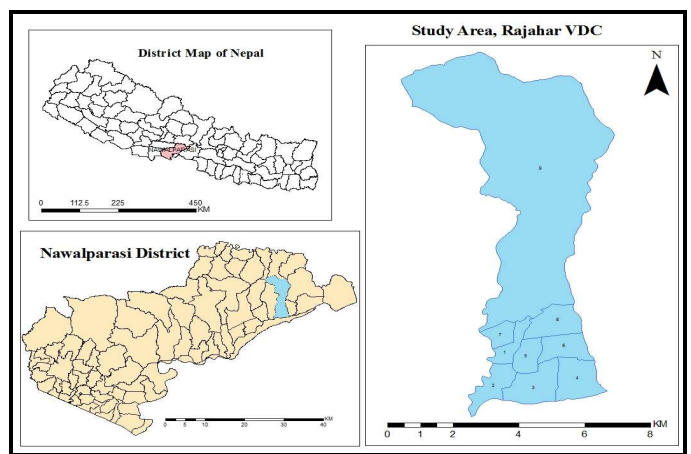

Fig. 1. Map of the study area.
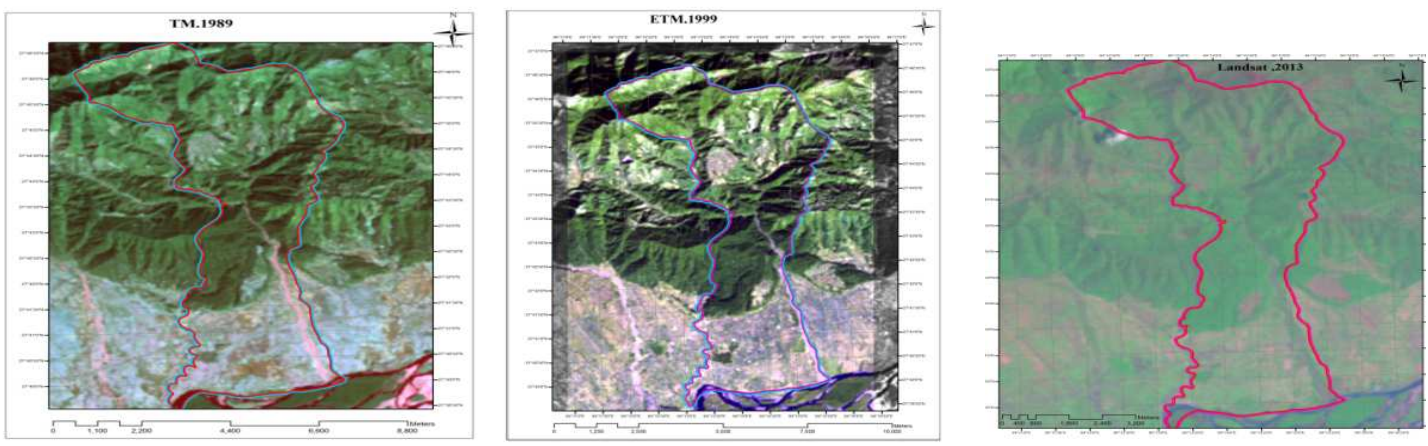

Fig. 2. Different landsat satellite images (Images 1989: Left, 1999: Middle and 2013: Right). 
Table 1. Satellite image used in land use classification.

\begin{tabular}{ccccc}
\hline Image & Path/Row & Pixel spacing & Satellite image sensor & Observation date \\
\hline Rajahar VDC & $142 / 041$ & $30 * 30 \mathrm{~m}$ & TM & $1989-11-07$ \\
Rajahar VDC & $142 / 041$ & $30 * 30 \mathrm{~m}$ & ETM+ & $1999-12-13$ \\
Rajahar VDC & $142 / 041$ & $30 * 30 \mathrm{~m}$ & Land sat8 & $2013-05-17$ \\
\hline
\end{tabular}

\section{GIS and RS image data analysis}

The GIS data analysis was based on pre field work, field work and post field work (Fig. 3). The land use classification scheme, first unsupervised image classification system was used for this study. Then supervised approach with the likelihood parameter was run to improve the accuracy of the land use classification for the images for all three dates (1989, 1999 and 2013). Supervised classification, which depends on training data and knowledge of ground situation, was carried out for accurate classification. The collected data in Landsat TM of 1989, ETM + 1999 and landsat8 2013 were objective base image analysis classified data. These were converted to vector that is file on Arc GIS 9.3 by using conversion tool. These shape files were classified into five (1989 and 1999) and six types in 2013 that is forest area, agriculture land, settlement area, water body, religious area and industrial area to observe the change in the land use of Rajahar VDC by different contrast colours to distinguish different land use classes. The land use changes of Rajahar VDC in three different periods over time were calculated by using geometric calculation (Rimal 2011). The analysis and interpretation of different aspects of the numeric data of land use dynamic were performed on Microsoft Excel.

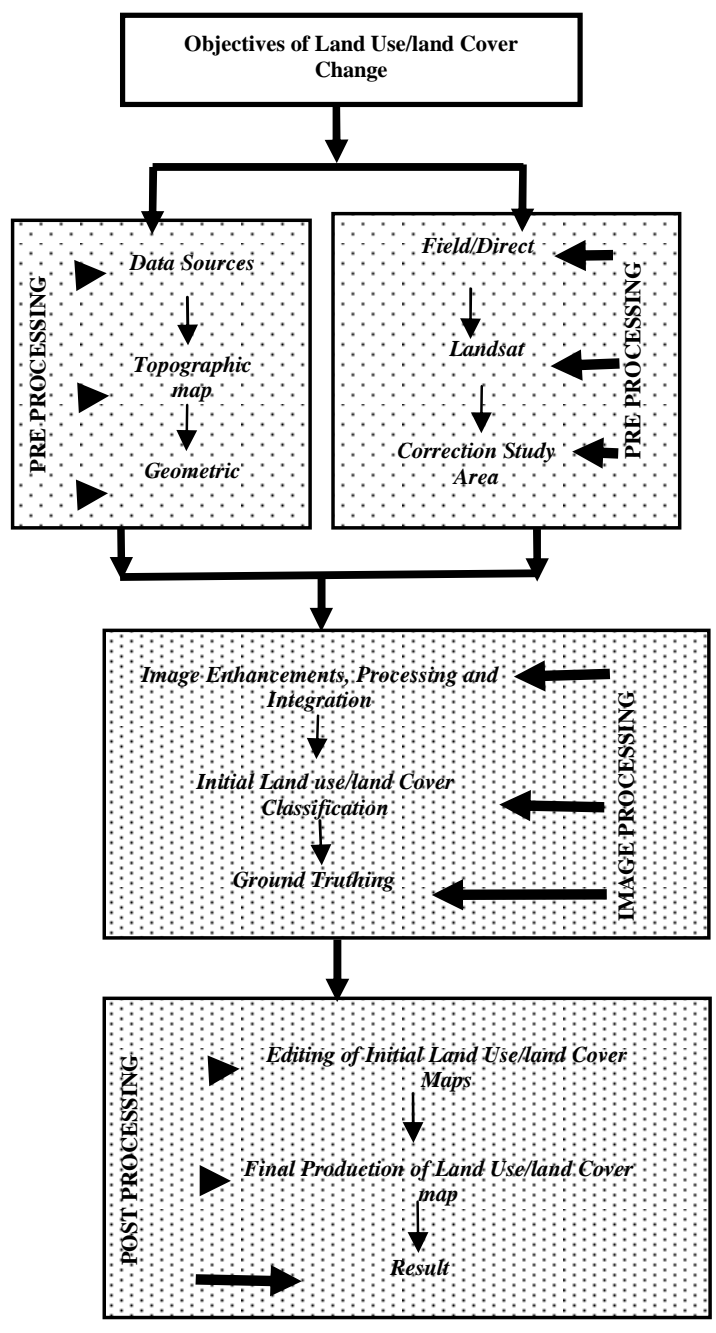

Fig. 3. Flow chart of methodology for remote sensing GIS application. 


\section{RESULTS AND DISCUSSION}

The application of Landsat TM image 1989, ETM+ image 1999 and Landsat8 image 2013 identified the major classes of land use and land cover change settings in the studied VDC. On the basis of obtained results, the image was classified as forest area, agricultural land, settlement area, water body, religious area for the study year 1989 and 1999 with additional industrial class (Industrial area) was inclusive in 2013 for the change in the land use land cover in Rajahar VDC (Table 2).

\section{Status of land use}

The GIS satellite image data analysis entailed that land use for forest was maximum with 27.619 sq $\mathrm{km}(69 \%)$ area followed by agriculture land $10.056 \mathrm{sq} \mathrm{km}(25.10 \%)$, settlement area $0.709 \mathrm{sq}$ $\mathrm{km}(25.10 \%)$, water body $1.66 \mathrm{sq} \mathrm{km}(4.14 \%)$, and religious area $0.012 \mathrm{sq} \mathrm{km}(0.03 \%)$ out of total land area of $40.056 \mathrm{sq} \mathrm{km}$ for 1989 A.D. (Figs. 4a and $4 b)$.

Similarly, data analysis of 1999 A.D. envisaged that the land use change as in the order of forest $27.306 \mathrm{sq} \mathrm{km}(68.15 \%)$, agricultural 9.915 sq km (24.71\%), settlement 0.689 sq km $(1.72 \%)$ and religious $0.005(0.01 \%)$ and water body $2.141 \mathrm{sq} \mathrm{km}(5.33 \%)$ out of total land use area of $40.056 \mathrm{sq} \mathrm{km} \mathrm{(Figs.} \mathrm{5a} \mathrm{and} \mathrm{5b).}$

Likewise, the forest area was $26.238 \mathrm{sq} \mathrm{km}$ $(65.48 \%)$ whereas agricultural land, settlement, water body and religious area were $10.858 \mathrm{sq} \mathrm{km}$ $(27.13 \%), 0.748 \mathrm{sq} \mathrm{km}(1.87 \%), 2.176 \mathrm{sq} \mathrm{km}$ $(5.43 \%)$ and $0.005 \mathrm{sq} \mathrm{km}(0.01 \%)$, respectively in 2013A.D. Industrial area with $0.031 \mathrm{sq} \mathrm{km}$ $(0.08 \%)$ area was recognized for the first time in 2013 A.D. (Figs. 6a and 6b).

Table 2. Land use pattern, Rajahar VDC.

\begin{tabular}{|c|c|c|c|c|c|c|c|}
\hline \multirow[t]{2}{*}{$\mathbf{S N}$} & \multirow[t]{2}{*}{ Land cover } & \multicolumn{2}{|c|}{1989} & \multicolumn{2}{|c|}{1999} & \multicolumn{2}{|c|}{2013} \\
\hline & & $\begin{array}{c}\text { Area } \\
(\mathbf{s q} \mathbf{k m})\end{array}$ & $\%$ & $\begin{array}{c}\text { Area } \\
(\mathbf{s q} \mathbf{k m})\end{array}$ & $\%$ & $\begin{array}{c}\text { Area } \\
(\mathbf{s q ~ k m})\end{array}$ & $\%$ \\
\hline 1 & Forest Area & 27.619 & 68.95 & 27.306 & 68.15 & 26.238 & 65.48 \\
\hline 2 & Agriculture Land & 10.056 & 25.10 & 9.915 & 24.77 & 10.858 & 27.13 \\
\hline 3 & Settlement Area & 0.709 & 1.77 & 0.689 & 1.72 & 0.748 & 1.87 \\
\hline 4 & Water Body & 1.66 & 4.14 & 2.141 & 5.35 & 2.176 & 5.43 \\
\hline 5 & Religious Area & 0.012 & 0.03 & 0.005 & 0.01 & 0.005 & 0.01 \\
\hline 6 & Industrial Area & 0 & 0 & 0 & 0 & 0.031 & 0.08 \\
\hline & Total & 40.056 & 100 & 40.056 & 100 & 40.056 & 100 \\
\hline
\end{tabular}

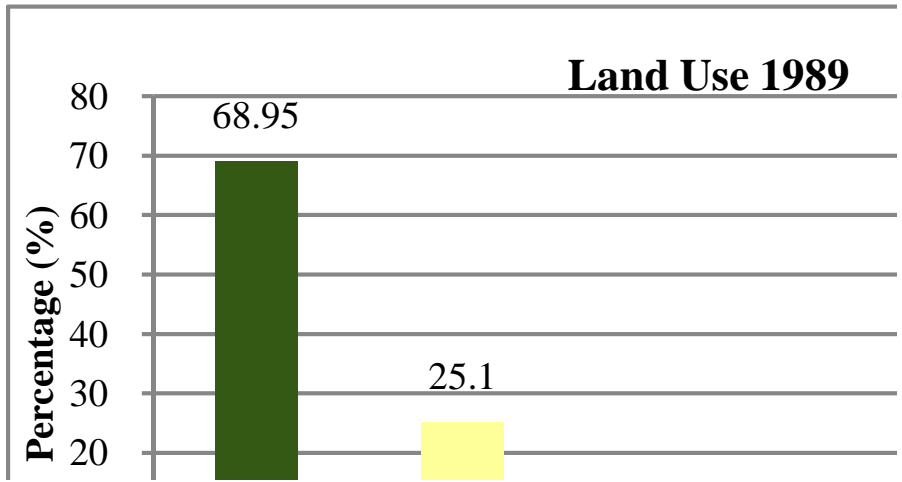

Fig. 4a. Land use 1989 histogram diagram.

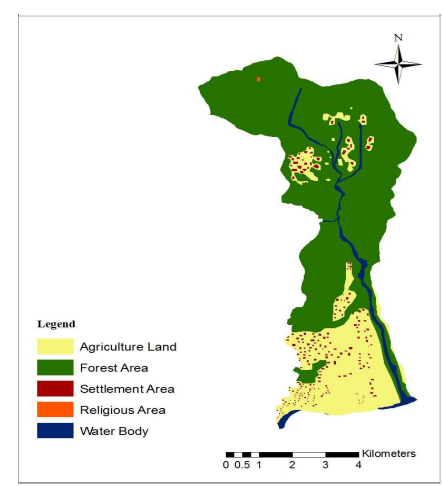

Fig. 4b. Rajahar VDC classified map, 1989. 


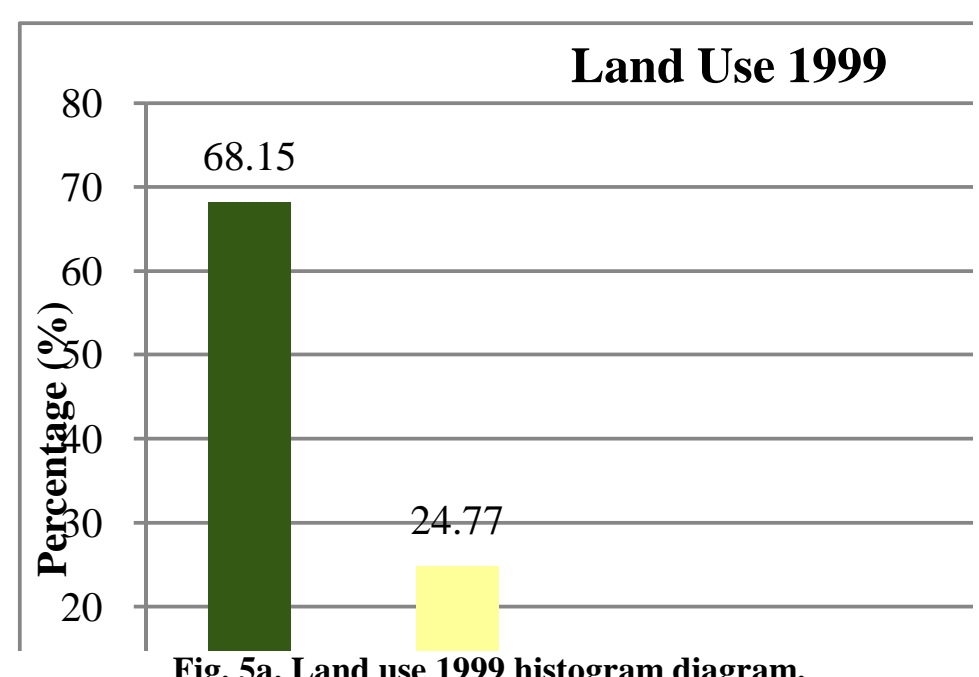

Fig. 5a. Land use 1999 histogram diagram.

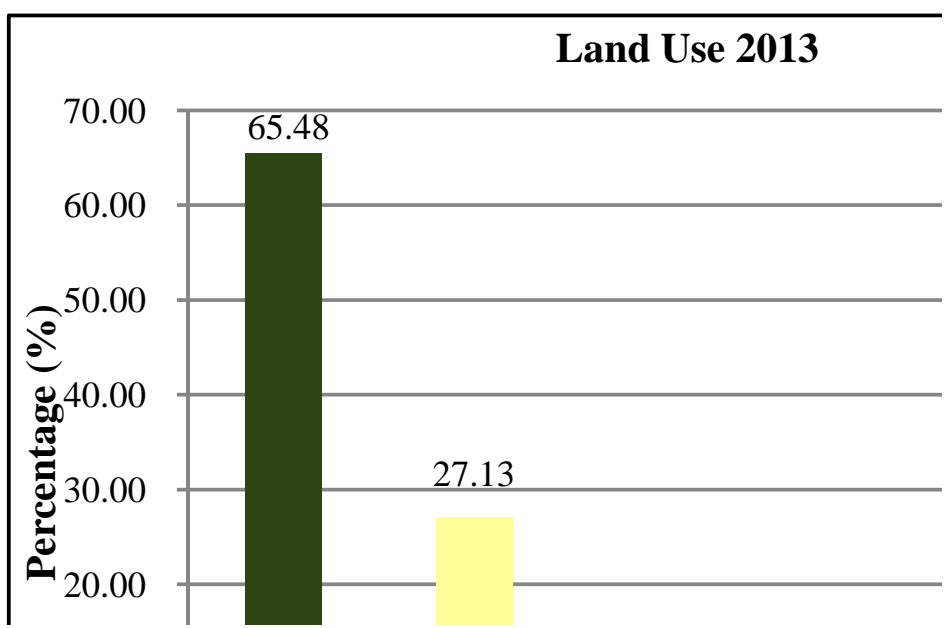

Fig. 6a. Land use 2013 histogram diagram.

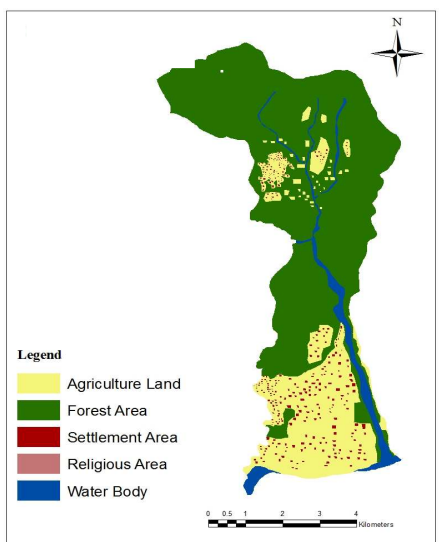

Fig. 5b. Rajahar VDC classified map, 1999.

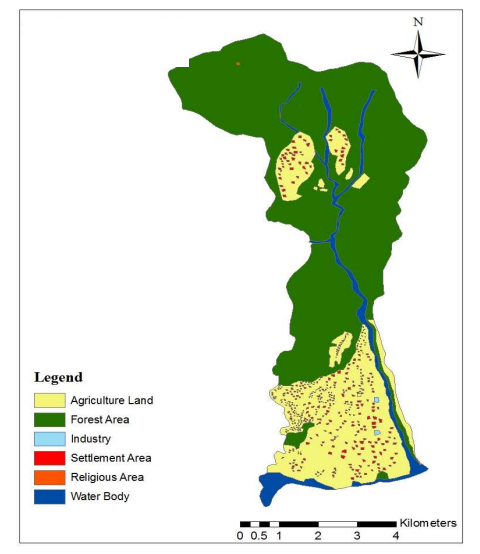

Fig. 6b. Rajahar VDC classified map, 2013.

\section{Land use changes}

The comparison of land use maps of 1989 to 1999 showed the considerable change in forest area $(-0.80 \%)$, agriculture land $(-0.33 \%)$, settlement area $(-0.04 \%)$, religious area $(-0.01 \%)$ and water body $(+1.19 \%)$. Between 1989 to 1999 forest areas, agriculture land, settlement and religious area were decreased whereas water body was increased (Fig. 7). Likewise, there was decrease in forest area $(-2.67 \%)$ whereas increase in agriculture land $(+2.35 \%)$, settlement area
$(+0.14 \%)$ and water body (+0.08\%) (Fig. 8). The religious area remained constant $(1.55 \%)$ in between 1999 to 2013. Similarly, the comparative study of land use change pattern from 1989 to 2013 showed there was considerable change in forest area $(-3.47 \%)$, religious area $(-0.01 \%)$. But agriculture land $(2.02 \%)$, settlement area $(3.66 \%)$ and water body $(1.28 \%)$ were increased. An additional industrial area $(0.07 \%)$ was identified as the new land use category (Fig. 9). 


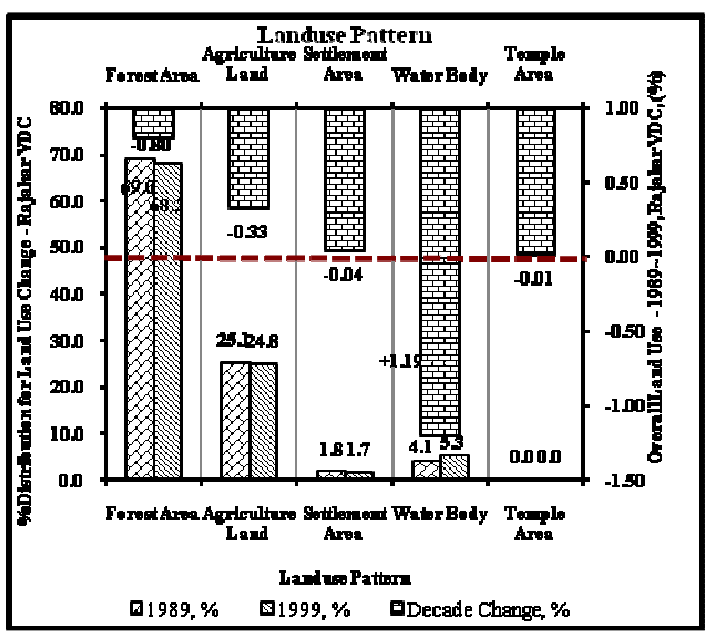

Fig. 7. Land use Pattern (1989 1999).

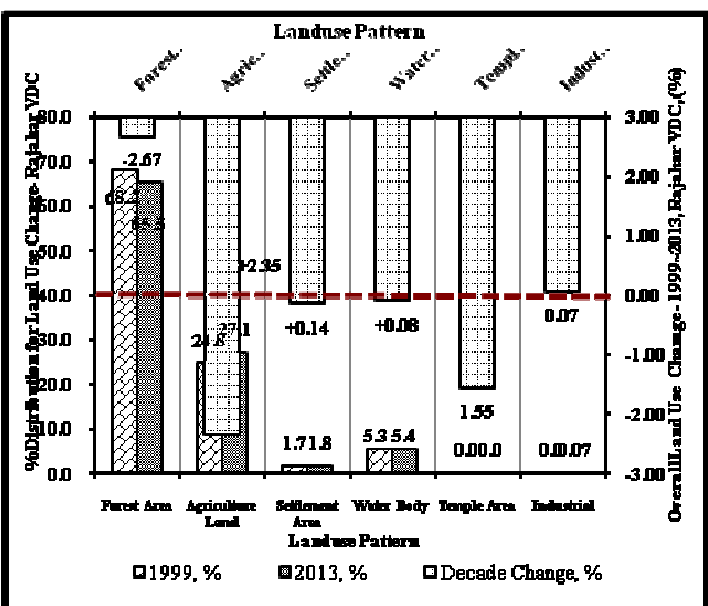

Fig. 8. Land use Pattern (1999 2013).

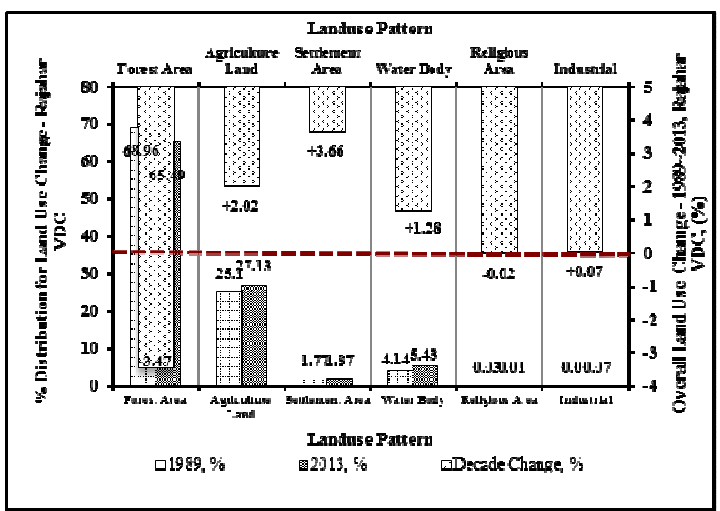

Fig. 9. Land use pattern (1989 2013).
Key drivers of land use change

According to the field analysis of primary information, the driving factors of land use change of the study were dependent on past events and reaction of the respondents. Seven key drivers (Table 3) were identified in the study area. They were dependent on forest and forest products (30\%); political situation (17\%); government policy, plans and land market (15\%); population growth (13\%); economic opportunities (11\%); infrastructure development (9\%); hotel and tourism activities (6\%), respectively (Fig. 10).

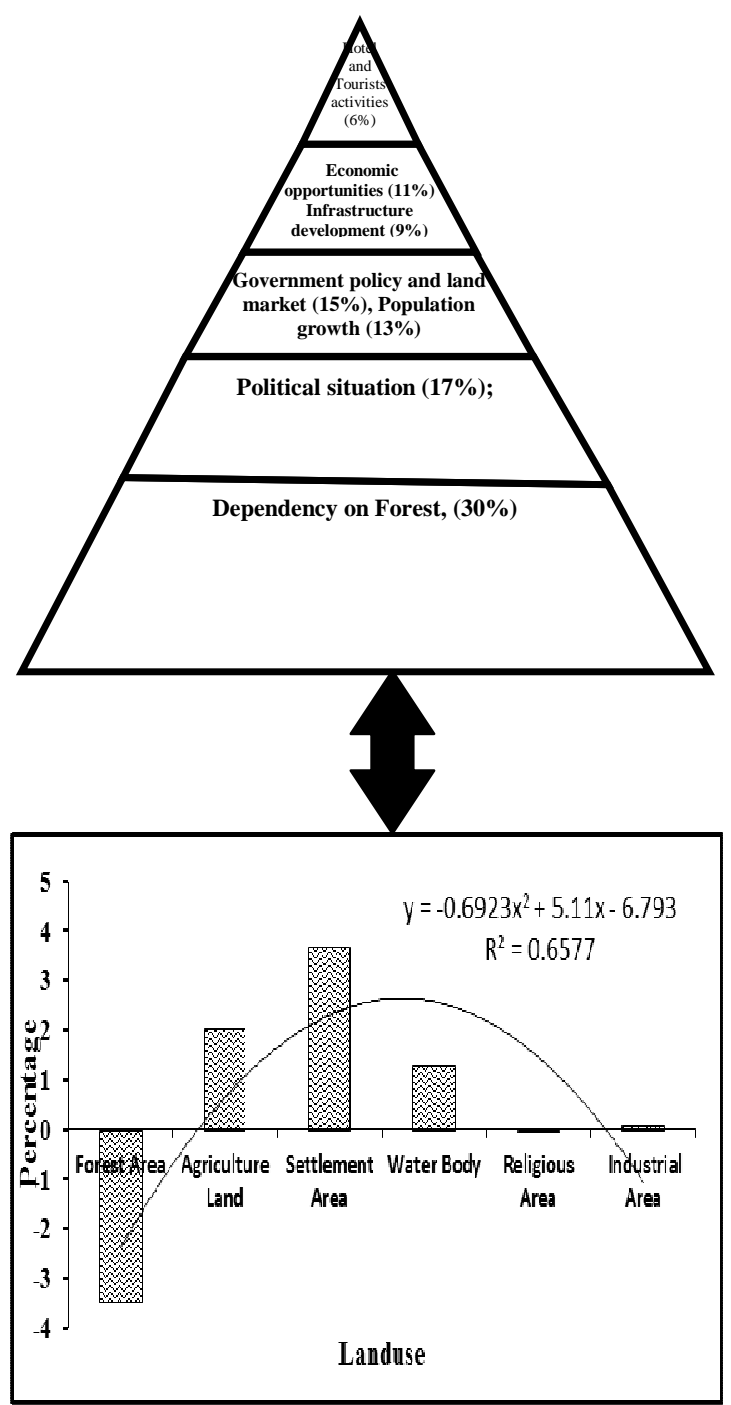

Fig. 10. Land use change with key drivers.

ECOPRINT VOL 21，2014 
Table 3. Key driving of land use changes, Rajahar VDC.

\begin{tabular}{|c|c|c|}
\hline SN & Key drivers & Frequency / (\%) \\
\hline 1. & $\begin{array}{l}\text { High dependency of forest and forest production (timber, firewood and other } \\
\text { NTFPs) }\end{array}$ & $16(30)$ \\
\hline 2. & Political situation & $9(17)$ \\
\hline 3. & Government policy, plans and land market & $8(15)$ \\
\hline & Population growth & $7(13)$ \\
\hline & Economic opportunities & $6(11)$ \\
\hline 6. & Infrastructure development & $5(9)$ \\
\hline 7. & Hotel and tourism activities & $3(6)$ \\
\hline \multicolumn{2}{|r|}{ Total } & $54(100)$ \\
\hline
\end{tabular}

Source: Based on field survey, 2013

Total respondents were divided into two parts, one part was village and other was the business activity at Bazaar area. Due to limited livelihood opportunity in some wards, local people had been involved in alcohol production business. This required high amount of firewood consumption and was regarded as the key drivers of deforestation. In Rajahar VDC, the study showed that major drivers of land use change were various socio-economic related activities, i.e., jobs and business opportunities in different sectors, finance, industry, education, health, etc.

The land use change between 1989 A.D. and 2013 A.D. followed the polynomial pattern (R2: 0.6577). The change was found dependent on forest and forest products (timber, firewood and other NTFPs), illegal and unsustainable harvesting practices, encroachment, opportunities, politics, population growth, governmental policies and plans, tourist's activities, land market, infrastructure development, resettlement, technology and overgrazing. In general, the key drivers of global forestland use change accompanied similar indicators (Dhital 2009), which were used in the present study.

Majority of households were highly dependent on forest products for the supply of primary energy source (timber and firewood). Besides, the timber products were also used in the local construction works. Due to lack of alternative income sources, the villagers utilized the forest products for better livelihood status, which finally declined the forest cover area. Population growth was taken as one of the drivers for land use change in developing economies all over the world (Groten et al. 1999). Besides, the land market had been rising up day by day. Large open field and cultivated lands had been plotted to small pieces and sold. Land polling and land reform system were considerable. Most of the respondents observed the change in political situations, which was regarded as the driver for population change.

\section{CONCLUSION}

The satellite images (1989 2013) were classified as forest area, agriculture land, settlement area, water body and religious area for $1989 \sim 1999$ whereas additional industrial area was inclusive in 2013.

- The comparative study of land use changes pattern in twenty four years (1989 2013) entailed that the forest $(-3.47 \%)$ and religious $(-0.01 \%)$ areas were reduced whereas agriculture land $(+2.02 \%)$, settlement area $(+3.66 \%)$ and water body $(+1.28 \%)$ were increased. The additional $0.07 \%$ industrial area was identified as new land use category for this interval. 
- The polynomial land use change pattern was observed in the study area $\left(R^{2}: 0.6577\right)$. The study showed that key drivers of land use change pattern were forest and forest products (timber, firewood and other NTFPs) high dependency, political situation, hotel and tourism activities, economic opportunities, infrastructure development, land market, population growth, government policies and plans.

\section{REFERENCES}

Anderson, J.K., E.E. Hardy,J.T. Roach and R.E. Witmer. 1976. A Land Use and Land Cover Classification System for Use with Remote Sensing Data. Geological Survey Professional Paper No. 964, Governmental Printing Office, Washington D.C., USA.

Briassoulis, H. 2006. Analysis of Land Use Change-Theoretical and Modeling Approaches. Regional Research Institute, West Virginia University. www.rri.wvu.edu/ WebBook/Briassoulis/contents. htm. pp. 269278.

CIESIN. 2002. Center for International Earth Science Information Network, A Thematic Guide to Land-Use and Land-Cover Change. New York, USA.

Dai, X.L. and S. Khorram. 1999. Remotely Sensed Change Detection Based on Artificial Neural Networks. Photogrammetric Engineering and Remote Sensing, 65(10):1187-1194.

Dhital, N. 2009. Reducing emissions from deforestation and forest degradation (REDD) in Nepal: Exploring the possibilities. Journal of Forest and Livelihood, 8(1).
FAO. 2005. Global Forest Resources Assessment, Progress towards Sustainable Forest Management. FAO, Rome, Italy.

Groten, S.M.E, W. Immerzeel and L.V. Leeuwen. 1999. Monitoring of Crops, Rangelands and Food Security at National Level. ITC-FAO, Rome, Italy.

Lamichhane, B.R. 2008. Dynamics and Driving Forces of Land Use/Forest Cover Changes and Indicators of Climate Change in Mountain Sub-watershed of Gorkha. Published Dissertation in Institute of Forestry (Tribhuvan University), Pokhara, Nepal.

Meyer, W.B. and B.L. Turner II. 1992. Human population growth and global land-use/cover change. Annu. Rev. Ecol. Syst. 23:39-61.

Phong, L.T. 2004. Analysis of Forest Cover Dynamics and their Forces in Bach Ma National Park and Buffer Zone Using Remote Sensing and GIS. Institute for Geo-information Sciences and Earth Observation, Enscheda, Netherland.

Rimal, B. 2011. Urban Development and Land Use Change of Main Nepalese Cities. Ph.D. Thesis Submitted to the Faculty of Earth Science and Environmental Management, University of Wroclaw.

Sharma, R.R. 2002. Monitoring Forest Resources Using Remote Sensing Data. www.gisdevelopment.net/aars/acrs/2002/for/ 167.pdf. 